\title{
Uji Efek Antibakteri Chromodoris annae terhadap Bakteri Staphylococcus aureus dan Escherichia coli
}

\author{
Aqueline N. Faidiban, ${ }^{1}$ Jimmy Posangi, ${ }^{2}$ Pemsi M. Wowor, ${ }^{2}$ Robert A. Bara ${ }^{2}$
}

\author{
${ }^{1}$ Program Studi Pendidikan Dokter Fakultas Kedokteran Universitas Sam Ratulangi Manado \\ ${ }^{2}$ Bagian Farmakologi Fakultas Kedokteran Universitas Sam Ratulangi Manado \\ Email: aqueline.faidiban@yahoo.com
}

\begin{abstract}
This study was aimed to evaluate the antibacterial effect of Chromodoris annae taken from Bunaken waters. This was an experimental study. The antibacterial effect was tested by using the Kirby-Bauer method. Chromodoris annae extract was made by maceration using $95 \%$ ethanol and was tested to Staphylococcus aureus and Escherichia coli bacteria. Ciprofloxacin was used as the positive control and aquadest as the negative control. The results showed that the mean inhibition zone diameter of Chromodoris annae extract to Staphylococcus aureus was $22.3 \mathrm{~mm}$ meanwhile of ciprofloxacin was $34.7 \mathrm{~mm}$. The mean inhibition zone diameter of Chromodoris annae extract to Escherichia coli was $23.0 \mathrm{~mm}$ meanwhile of ciprofloxacin was $40.3 \mathrm{~mm}$. Moreover, aquadest showed no inhibition zone. In conclusion, Chromodoris annae had very strong antibacterial effect to the growths of Staphylococcus aureus and Escherichia coli.
\end{abstract}

Keywords: Chromodoris annae, Staphlococcus aureus, Escherichia coli

\begin{abstract}
Abstrak: Penelitian ini bertujuan untuk mengevaluasi efek antibakteri dari Chromodoris annae yang diambil dari perairan Bunaken. Jenis penelitian ialah eksperimental. Pengujian aktivitas antibakteri menggunakan metode Kirby-Bauer. Ekstrak Chromodoris annae dibuat dengan cara maserasi menggunakan pelarut etanol $95 \%$ dan diujikan aktivitas antibakteri terhadap bakteri Staphylococcus aureus dan Escherichia coli. Sebagai kontrol positif digunakan antibiotik ciprofloxacin dan sebagai kontrol negatif digunakan akuades. Hasil penelitian memperlihatkan rerata zona hambat ekstrak Chromodoris annae terhadap Staphylococcus aureus sebesar 22,3 $\mathrm{mm}$ sedangkan zona hambat ciprofloxacin sebesar $34,7 \mathrm{~mm}$. Rerata zona hambat ekstrak Chromodoris annae terhadap Escherichia coli sebesar 23,0 $\mathrm{mm}$ sedangkan zona hambat ciprofloxacin sebesar 40,3 mm. Akuades tidak memperlihatkan adanya zona hambat. Simpulan penelitian ini ialah Chromodoris annae memiliki efek antibakteri kategori sangat kuat terhadap pertumbuhan bakteri Staphylococcus aureus dan Escherichia coli.
\end{abstract}

Kata kunci: Chromodoris annae, Staphylococcus aureus, Escherichia coli

\section{PENDAHULUAN}

Alam terus menyediakan berbagai macam senyawa yang memiliki aktivitas farmakologis yang dapat digunakan untuk melawan berbagai macam penyakit. ${ }^{1 .}$ Indonesia merupakan negara kepulauan terbesar yang sangat kaya akan potensi laut baik hayati maupun non-hayati. Lautan Indonesia memiliki 8.500 spesies ikan, 555 spesies rumput laut dan 950 spesies biota yang berasosiasi dengan ekosistem terumbu karang. ${ }^{2}$ Nudibranchia adalah kelompok siput yang sangat menarik dengan variasi warna, pola tubuh, dan merupakan pemakan porifera. Pada tubuh porifera terdapat racun yang merupakan salah bentuk adaptasi terhadap predator. ${ }^{3}$

Antibiotik adalah senyawa antimikroba yang digunakan untuk mengobati penyakit infeksi yang disebabkan oleh bakteri. Senyawa ini dihasilkan oleh mikroorganisme. Sejarah penemuan antibiotik dimulai 
saat Fleming menemukan penisilin sebagai antibiotik pertama pada tahun 1929 kemudian digunakan secara umum pada tahun 1940. Pada tahun tersebut antibiotik merubah dunia pengobatan dengan mengurangi angka kesakitan dan kematian yang disebabkan oleh penyakit infeksi secara dramatis. $^{4}$

Staphylococcus aureus merupakan salah satu bakteri Gram positif yang sering ditemukan sebagai kuman flora normal pada kulit dan selaput lendir manusia. Bakteri ini bersifat patogen dan dapat menjadi penyebab infeksi pada manusia dan hewan. ${ }^{5}$ Escherichia coli merupakan bakteri Gram negatif yang ditemukan pada usus besar manusia dan bersifat aerob. Bakteri ini menjadi patogen bila mencapai jaringan di luar saluran cerna khususnya saluran kemih, saluran empedu, paru-paru, dan pada selaput otak dapat menyebabkan peradangan. ${ }^{6}$

\section{METODE PENELITIAN}

Penelitian ini dilaksanakan di Laboratorium Farmakologi Fakultas Kedokteran Sam Ratulangi Manado pada bulan Oktober 2015 sampai Januari 2016. Jenis penelitian ini ialah eksperimental.

Pengambilan sampel Chromodoris annae yaitu salah satu jenis Nudibranchia dilakukan dengan menyelam di perairan Bunaken (Gambar 1). Ekstrak Chromodoris annae dibuat dengan metode maserasi menggunakan pelarut etanol $96 \%$.

Uji efek antibakteri menggunakan metode sumuran, dengan cara mengamati terbentuknya daerah jernih di sekitar sumur yang ditetesi dengan ekstrak Chromodoris annae. Antibiotik pembanding ialah Ciprofloxacin sebagai kontrol positif dan akuades sebagai kontrol negatif.

Ekstrak Chromodoris annae diujikan pada bakteri Staphylococcus aureus dan Escherichiacoli sebagai bakteri uji. Pembuatan media menggunakan Brain Heart Infusion (BHI), dan Nutrient Agar (NA). Daerah jernih sekeliling media pertumbuhan bakteri uji diukur dengan menggunakan penggaris dan kemudian dilakukan pengolahan data.

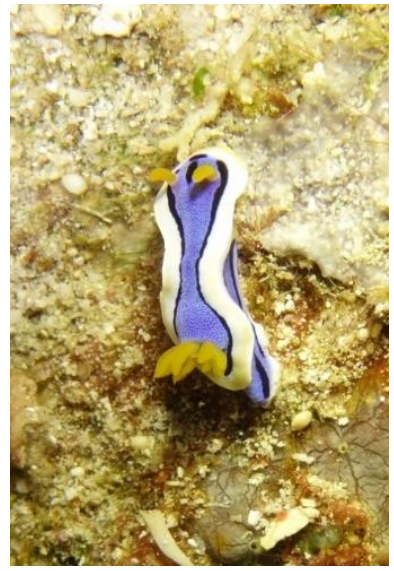

Gambar 1. Spesies Chromodoris annae yang diambil pada perairan Bunaken

\section{HASIL PENELITIAN}

Sampel diambil di perairan Bunaken dengan cara menyelam menggunakan peralatan SCUBA pada kedalaman 9-18 m dan kemjudian diisi dalam wadah tertutup. Pembuatan ekstrak dengan cara tubuh sampel dipotong menjadi berapa bagian dan dimasukkan ke dalam eppendorf $2 \mathrm{ml}$ yang sebelumnya telah diisi etanol $95 \%$ dan dibiarkan selama 24 jam. Kemudian ekstrak sampel diambil menggunakan pipet dan diteteskan ke dalam sumuran yang sudah dibuat pada cawan Petri.

Zona hambat diukur menggunakan penggaris dengan satuan milimeter $(\mathrm{mm})$. Pengamatan zona hambat dilakukan dengan cara mengukur diameter horizontal dan diameter vertikal dari zona hambat yang terbentuk di sekitar sumur. Kedua diameter tersebut dimasukkan ke dalam rumus untuk mencari rerata diameter zona hambat. Hasil pengukuran diameter zona hambat ekstrak Chromodoris annae yang terhadap kedua bakteri uji dapat dilihat pada Tabel 1 dan 2 .

Tabel 1 memperlihatkan diameter zona hambat ekstrak Chromodoris annae terhadap bakteri Staphylococcus aureus. Diameter rerata zona hambat ekstrak $C$. annae $(22,3 \mathrm{~mm})$ lebih kecil daripada diameter rerata zona hambat ciprofloxacin $(34,7 \mathrm{~mm})$.

Tabel 2 memperlihatkan diameter zona hambat ekstrak Chromodoris annae terhadap bakteri Escherichia coli. Diameter rerata zona hambat ekstrak $C$. annae $(22,3$ $\mathrm{mm})$ lebih kecil daripada diameter rerata zona hambat ciprofloxacin $(34,7 \mathrm{~mm})$. 
Tabel 1. Diameter zona hambat ekstrak Chromodoris annae terhadap bakteri Staphylococcus aureus (dalam ukuran $\mathrm{mm}$ )

\begin{tabular}{cccc}
\hline Ulangan & $\begin{array}{c}\text { Ekstrak } \\
\text { C. annae }\end{array}$ & $\begin{array}{c}\text { Kontrol } \\
(+)\end{array}$ & $\begin{array}{c}\text { Kontrol } \\
(-)\end{array}$ \\
\hline 1 & 22 & 35 & tn \\
2 & 24 & 34 & tn \\
3 & 22 & 35 & tn \\
Rerata & 22,3 & 34,7 & \\
\hline
\end{tabular}

tn=tidak nampak zona hambat

Tabel 2. Diameter zona hambat ekstrak Chromododris annae terhadap bakteri Escherichia coli (dalam mm)

\begin{tabular}{cccc}
\hline Ulangan & $\begin{array}{c}\text { Ekstrak } \\
\text { C. } \text { annae }\end{array}$ & $\begin{array}{c}\text { Kontrol } \\
(+)\end{array}$ & $\begin{array}{c}\text { Kontrol } \\
(-)\end{array}$ \\
\hline 1 & 22 & 39 & tn \\
2 & 24 & 41 & tn \\
3 & 23 & 39 & tn \\
Rerata & 23,0 & 40,3 & \\
tn=tidak nampak zona hambat & &
\end{tabular}

\section{BAHASAN}

Pengambilan sampel dilakukan di perairan Bunaken dan diteliti di Laboratorium Fakultas Kedokteran Sam Ratulangi Manado. Pengujian daya hambat dilakukan dengan menggunakan zona hambat yang dihasilkan pada media yang mengandung bakteri Staphylococcus aureus dan Escherichia coli setelah diinkubasi selama 24 jam pada suhu $37^{\circ} \mathrm{C}$.

Terbentuknya zona hambat terhadap bakteri Staphylococcusaureus di sekitar sumur yang diberikan ekstrak Chromodoris annae menunjukkan adanya aktivitas antibakteri dari ekstrak tersebut terhadap pertumbuhan bakteri Staphylococcus aureus. Walaupun diameter rerata zona hambat ekstrak $C$. annae $(22,3 \mathrm{~mm})$ lebih kecil daripada diameter rerata zona hambat ciprofloxacin $(34,7 \mathrm{~mm})$ tetapi telah tergolong pada kategori sangat kuat menurut Davis \& Stout (1971). ${ }^{7}$ Hal yang sama terlihat pada terbentuknya zona hambat terhadap bakteri Staphylococcusaureus di sekitar sumur yang diberikan ekstrak Chromodoris annae yang menunjukkan adanya aktivitas antibakteri dari ekstrak tersebut terhadap pertumbuhan bakteri
Staphylococcus aureus. Walaupun diameter rerata zona hambat ekstrak C. annae $(23,0$ $\mathrm{mm})$ lebih kecil daripada diameter rerata zona hambat ciprofloxacin $(40,3 \mathrm{~mm})$ tetapi telah tergolong pada kategori sangat kuat menurut Davis \& Stout (1971). Semakin lebar zona hambat yang terbentuk, mengindikasikan semakin kuatnya senyawa bioaktif yang terdapat di dalam spesies tersebut. $^{8}$

Hasil penelitian menunjukkan bahwa Chromodoris annae dapat menghambat kedua bakteri uji yang merupakan bakteri Gram positif dan bakteri Gram negatif. Dengan membandingkan hasil kemampuan hambat ekstrak dengan kontrol positif dapat dilihat bahwa kontrol positif masih memberikan daya hambat yang lebih kuat terhadap bakteri uji, ${ }^{9}$ sedangkan di sekitar sumur yang diberi akuades sebagai kontrol negatif tidak ditemukan zona hambat karena akuades merupakan larutan pengencer pada kontrol positif. Dalam penelitian ini tampak bahwa ciprofloxasin lebih efisien dalam menghambat pertumbuhan bakteri. Faktor yang memengaruji terjadinya hal tersebut yakni minimal inhibitory concentration (MIC) ciprofloxasin telah diketahui sedang- 
kan kemampuan ekstrak Chromodoris annae belum diketahui konsentrasi paling tepat untuk menghambat pertumbuhan bakteri. ${ }^{10}$ Pemilihan ciprofloxacin sebagai kontrol positif dengan pertimbangan Ciprofloxacin merupakan antibiotik spektrum luas (broad spectrum), dan termasuk dalam golongan florokuinolon yang paling umum digunakann dengan mekanisme kerja menghambat DNA girase (topoisomerase II) dan topoisomerase IV yang terdapat dalam bakteri. ${ }^{11}$ Penghambatan terhadap enzim yang terlibat dalam replikasi, rekombinasi dan reparasi DNA tersebut mengakibatkan penghambatan terhadap pertumbuhan sel bakteri.

\section{SIMPULAN}

Chromodoris annae memiliki sifat antibakteri yang tergolong sangat kuat terhadap bakteri Staphylococcus aureus dan Escherichia coli.

Disarankan untuk penelitian lanjut dengan uji sensitivitas spesies Chromodoris annae terhadap bakteri.

\section{Konflik Kepentingan}

Penulis menyatakan tidak terdapat konflik kepentingan dalam studi ini.

\section{DAFTAR PUSTAKA}

1. Bara RA, Kandou GD, Ola ARB, Posangi J. Analisis senyawa Bioaktif dari jamur simbion yang terdapat dalam ascidians Didemnum molle di sekitar perairan Sulawesi Utara. Jurnal LPPM Bidang Sains dan teknologi. 2015;2(2):28-35.

2. Siregar IY. Menggali Potensi Sumber Daya Laut Indonesia [Skripsi]. Pekanbaru
Riau: Universitas Bina Widya; 2015.

3. Kaligis F, Bara RA. 2015. Biodiversity and antibacterial secondery metabolites from sea slugs collected from North Sulawesi Waters, Indonesia. Research Proposal International Research Collaboration and Scientific Publication. North Sulawesi and Germany: Sam Ratulangi University and Zoological Research Museum Bonn.

4. Aidilfiet C. Buku Ajar Mikrobiologi Kedokteran (Edisi Revisi). Jakarta: Bina Rupa Aksara, 2010.

5. Noviana H. Pola kepekaan antibiotik Escherichia coli yang diisolasi dari berbagai specimen klinis. Jurnal Kedokteran Trisakti. 2004;23:123.

6. Gosliner TM, Behrens DW. Five new species of chromodoris (Mollusca: Nudibranchia: chromodorididae) from the tropical Indo-West pacific. Proceedings of the California Academy of Sciences. 1998; 50(5):139-65.

7. Tortora G, Francisco BR. Case CL. Microbiology: an Introduction (10th ed). San Francisco: Pearson Education Inc, 2009; p.79-88.

8. Irianto K. Mikrobiologi Menguak Dunia Mikroorganisme Jilid 1 (2nd ed). Bandung: Yrama Widya, 2007; p. 34-58.

9. Setiabudy R Antimikroba. In: Farmakologi dan Terapi (5th ed). Jakarta: EGC, 2008; p. 585.

10. Mohanasundaram S. Effect of duration of treatment on ciprofloxacin induced arthropathy in young rats. Indian Journal of Pharmacology. 2001;33:100-3.

11. Sarro AD, Sarro GD. Adverse reactions to fluorquinolones. an overview on mechanism aspects. Curr Med Chem. 2001;8:371-84. 